\title{
PENDELEGASIAN PENGATURAN OLEH UNDANG- UNDANG KEPADA PERATURAN YANG LEBIH RENDAH DAN AKIBAT HUKUMNYA
}

\author{
Oleh: \\ Sukardi dan E. Prajwalita Widiati*
}

\begin{abstract}
Act is an essential instrument in the rule of law. As the basic for governmental regulation, the accuracy and legality of its drafting process should be placed as the main concern. This article examines such models of delegated legislation. In severe legislation product, some problems regarding the mistaken in the delegation process was still founded. This article recommends the importancy of limiting substance for each level of regulation to avoid redundancy. Regulation synchronization is needed in order to avoid inefficiency and reach the maximum aim of what the regulations is made for.
\end{abstract}

Key words: legislation, regulation, delegation.

\section{PENDAHULUAN}

Undang-undang merupakan instrumen penting bagi suatu negara hukum. Jika konstitusi (UUD NRI 1945) memuat norma-norma fundamental kehidupan ketatanegaraan bangsa Indonesia, maka sesungguhnya pemerintah dan masyarakat membutuhkan pedoman yang menjelaskan lebih rinci ketentuan-ketentuan yang digariskan dalam konstitusi, serta panduan yang memuat perintah apa yang harus dan tidak boleh dilakukan. Undang-undang juga memuat sanksi sebagai pemaksa agar terwujud suatu keteraturan dalam pelaksanaan hak dan kewajiban.

Undang-undang bagi kehidupan berbangsa dan bernegara adalah juga merupakan implementasi asas legalitas, nullum delictum nulla poena sinne praevia lege poenali di mana seseorang tidak dapat dihukum tanpa ada ketentuan yang mendahului perbuatan yang dilarang itu. Selain demi menjamin kepastian hukum, asas legalitas memiliki dua fungsi lain yakni, sebagai tolok ukur keabsahan tindakan penguasa, dan sebagai jaminan perlindungan bagi subjek hukum dalam negara ${ }^{1}$.

Prof. Siti Sundari Rangkuti dalam bukunya juga mengatakan posisi penting undang-undang. "Undang-undang merupakan landasan hukum yang menjadi dasar pelaksanaan dari seluruh kebijakan yang akan dibuat oleh Pemerintah. Legal policy yang dituangkan dalam undangundang menjadi sebuah sarana rekayasa sosial yang memuat kebijaksanaan

\footnotetext{
* Dosen Fakultas Hukum Universitas Airlangga

${ }^{1}$ ELSAM (Lembaga Studi dan Advokasi Masyarakat), Position Paper Advokasi RUU KUHPSeri\#1 Asas Legalitas Dalam Rancangan KUHP,
} 
yang hendak dicapai pemerintah, untuk mengarahkan masyarakat menerima nilainilai baru". ${ }^{2}$

Dengan urgensi yang dimilikinya, mestinya pembentukan undang-undang serta pengaturan yang bersumber pada undangundang menjunjung tinggi kecermatan. Pada faktanya, dari 205 perkara yang diputus oleh Mahkamah Konstitusi dalam kurun 20032005, sejumlah 150 diantaranya adalah perkara pengujian undang-undang. ${ }^{3} \mathrm{Hal}$ ini menandakan masih perlunya perhatian khusus pemerintah dalam menjaga kualitas produk hukumnya. Padahal, pengaturan yang didasarkan pada undang-undang yang diujikan itu, tentu tidak sedikit jumlahnya. Dapat dibayangkan, bagaimana wajah hukum kita jika dilihat dari wajah produk hukum yang kita hasilkan.

Permasalahan lain yang dapat digali dari banyaknya pengajuan uji materiil undang-undang adalah banyaknya konflik norma dalam undang-undang itu sendiri, bahkan tidak jarang ada pengaturan di bawah undang-undang yang seharusnya bersumber pada undang-undang justru muatannya bertentangan.

"... dalam pertimbangannnya Mahkamah (Mahkamah Konstitusi-pen) menyebutkan Undang-undang nomor 21 tahun 2001 tidak taat asas (inkonsisten) dan bersifat mendua (ambivalen). Inkonsistensi dan ambivalensi itu tersebut terlihat dalam penjelasan umum Undang-undang a quo yang mengakui wilayah provinsi papua barat terdiri atas 12 kabupaten dan 2 kota.........sementara itu Undang-undang nomor 21 tahun 2001 tidak menyinggung sedikitpun keberadaan provinsi Irian Jaya Barat dan Irian Jaya Tengah, padahal kedua provinsi itu dibentuk dengan Undang-undang nomor 45 tahun 1999"4

Kemudian mahkamah menyebutkan pula

"... materi muatan yang diatur kedua undangundang tersebut berbeda namun dalam beberapa hal bersinggungan, yang pada gilirannya menimbulkan konflik dalam pelaksanaannya"

Dari kutipan ini dapat terlihat konflik norma antara Undang-undang yang satu dengan undang-undang yang lain.

Lain lagi halnya dengan Peraturan Pemerintah yang merupakan satu jenis pengaturan yang merupakan bentuk pendelegasian atau penjabaran lebih lanjut pengaturan dari Undang-undang. Menurut ketentuan pasal 5 ayat (2) UUD NRI 1945, "Presiden menetapkan peraturan pemerintah untuk menjalankan undangundang sebagaimana mestinya". Ini berarti pendelegasian dibuatnya Peraturan Pemerintah tetap dapat berlangsung baik dengan atau tanpa disebutkan oleh Undangundang. Lebih lanjut bahwa yang terpenting dari dibuatnya PP oleh Pemerintah adalah adanya syarat dari frasa "sebagaimana mestinya". ${ }^{5}$ Berdasarkan norma dalam pasalpasal ini, maka apakah Peraturan Pemerintah yang tidak diperintahkan pendelegasiannya oleh Undang-undang dapat dikatakan bertentangan dengan Undang-undang? atau Apakah mungkin pendelegasian Undang-undang kepada peraturan yang lebih rendah dapat berupa bentuk selain Peraturan Pemerintah? Apakah peraturan di bawah Peraturan Pemerintah dapat bersumber langsung pada Undang-undang tanpa harus merujukkan pada Peraturan

\footnotetext{
${ }^{2}$ Siti Sundari Rangkuti, Hukum Lingkungan dan Kebijaksanaan Lingkungan Nasional (edisi ketiga), Surabaya, Airlangga University Press, 2005, hal. 12.

${ }^{3}$ Ikhtisar Putusan Mahkamah Konstitusi 2003-2008, Jakarta, Sekretariat MK, 2008.

${ }^{4}$ Ibid, hal. 89 (Putusan Perkara Nomor 018/PUU-I/2003 tentang Provinsi Papua)

${ }^{5}$ Lihat Pasal 10 Undang-undang Nomor 10 Tahun 2004 tentang Pembentukan Peraturan Perundang-undangan beserta penjelasan. Lihat juga Pasal 7.
} 
Pemerintah? Tulisan ini hendak menelusuri pendelegasian pengaturan oleh Undangundang kepada aturan yang lebih rendah serta akibat-akibat hukum yang mungkin timbul dari pendelegasian tersebut.

\section{PEMBAHASAN}

Dalam Ilmu Hukum Perundangundangan dikenal adanya hierarkhi norma hukum atau jenjang-jenjang norma hukum. Teori mengenai jenjang norma hukum ini dikaitkan pada ajaran Hans Kelsen tentang stufentheori yang mengatakan bahwa suatu norma yang lebih rendah berlaku, bersumber dan berdasar pada norma yang lebih tinggi, norma tersebut juga bersumber dan berdasar pada norma yang lebih atas lagi dan seterusnya sampai pada suatu norma yang tidak dapat ditelusuri lebih lanjut yang sifatnya hipotetis atau fiktif yaitu norma dasar (grundnorm). ${ }^{6}$ Jenjang-jenjang ini memberikan arti bahwa suatu aturan bersumber dari aturan di atasnya sehingga ia tidak boleh bertentangan dengan aturan di atasnya.

Hierarkhi peraturan perundangundangan Indonesia ditunjukkan oleh Pasal 7 ayat (1) Undang-undang Nomor 10 Tahun 2004 tentang Pembentukan Peraturan Perundang-undangan. "(1). Jenis dan hierarki Peraturan Perundangundangan adalah sebagai berikut: a. UndangUndang Dasar Negara Republik Indonesia Tahun 1945; b. Undang-Undang/Peraturan Pemerintah Pengganti Undang-Undang; c. Peraturan Pemerintah; d. Peraturan Presiden; e. Peraturan Daerah.

Undang-undang sebagai produk hukum yang dinamakan oleh konstitusi untuk mengatur lebih lanjut norma dasar di dalam konstitusi, memiliki kedudukan yang esensi. Pemerintah dan masyarakat membutuhkan norma hukum yang lebih konkrit dan rinci yang dapat langsung diimplementasikan, yang menunjukkan bagaimana cara mereka menjalankan apa yang sudah diatur dalam konstitusi, disinilah Undang-undang mengambil peran. Dalam hierarkhi, Undang-undang berada di posisi formell gezets di bawah grundnorm.

Esensi dari wewenang pembentukan peraturan perundang-undangan adalah bahwa semakin tinggi tingkatan lembaga pembentuk peraturan, maka semakin tinggi pula tingkatan peraturan yang dibentuknya dalam hierarkhi peraturan perundangundangan.

Materi muatan yang harus diatur dengan Undang-Undang berisi hal-hal yang:

a. mengatur lebih lanjut ketentuan UndangUndang Dasar Negara Republik Indonesia Tahun 1945 yang meliputi:

1. hak-hak asasi manusia;

2. hak dan kewajiban warga negara;

3. pelaksanaan dan penegakan kedaulatan negara serta pembagian kekuasaan negara;

4. wilayah negara dan pembagian daerah;

5. kew arganegara a d a n kependudukan;

6. keuangan negara.

b. diperintahkan oleh suatu Undang-Undang untuk diatur dengan Undang-Undang. ${ }^{7}$

Dari pasal ini dapat ditemukan dua hal esensi yang menjadi tugas Undangundang mengaturnya. Pertama adalah mem"breakdown" tentang 6 hal ketentuan dalam konstitusi, Kedua adalah mengatur hal-hal di luar itu yang belum tercakup pengaturannya dalam suatu Undang-undang, misalnya Undang-undang tentang Pemilu Anggota DPR, DPD, dan DPRD tentu saja perlu didukung Undang-undang tentang

\footnotetext{
${ }^{6}$ Hans Kelsen, General Theory of Law and State, New York, Russell \& Russell, 1945, hal. 35.

${ }^{7}$ Pasal 8 Undang-undang Nomor 10 Tahun 2004
} 
MPR, DPR, DPD dan DPRD, undangundang yang pertama mengatur bagaimana mekanisme anggota badan perwakilan dipilih, sedangkan yang kedua mengatur bagaimana anggota badan perwakilan bekerja dan mempertanggungjawabkan pekerjaannya. Sehingga sesungguhnya semua pengaturan dalam Undang-undang itu saling terkait satu dengan yang lain, hal ini terlihat pada konsiderans "mengingat" di setiap Undangundang. Untuk kepentingan inilah, dalam naskah akademik persiapan RUU terdapat kajian perundang-undangan, dimana drafter harus mengkaji semua peraturan terkait dengan masalah, dan menemukan apakah sudah ada pengaturan sebelumnya? Jika ada apakah sudah ada pengaturan pelaksananya? Hingga berdasarkan kajian itu disimpulkan perlunya dibuat aturan baru untuk melengkapi pengaturan yang sudah ada. Kajian perundang-undangan dalam persiapan Naskah Akademik RUU sekaligus sebagai upaya untuk mencegah terjadinya konflik norma dalam pengaturan.

Tahapan ketiga setelah mengkaji Undang-undang dari segi wewenang pembentukan dan materi muatan, adalah asas-asas pembentukan perundangundangan. Mengenai asas-asas pembentukan ini Bagir Manan berpendapat seperti dikutip di buku Prof. Yuliandri berjudul Asasasas Pembentukan Peraturan Perundangundangan yang baik bahwa landasan pembentukan peraturan perundangundangan harus mengacu pada landasan yuridis, landasan sosiologis dan landasan filosofis ${ }^{8}$. Landasan yuridis penting karena, pertama terkait dengan keharusan adanya kewenangan dari pejabat pembuat produk hukum, yang; kedua terkait dengan keharusan adanya kesesuaian bentuk atau jenis produk hukum dengan materi yang diatur; ketiga keharusan mengikuti cara tertentu yakni tahapan-tahapan mulai proses persiapan naskah akademik, pengajuan rancangan, pembahasan, pengesahan hingga pengundangan; keempat, keharusan tidak bertantangan dengan peraturan-perundangundangan yang lebih tinggi tingkatannya. Landasan kedua adalah landasan sosiologis dimana suatu peraturan perundang-undangan harus menjawab dan menyelesaikan masalah yang terjadi di masyarakat. "Suatu hal yang harus diingat bahwa kenyataan yang hidup dalam masyarakat sebagai dasar sosiologis harus termasuk pula kecenderungankecenderungan dan harapan-harapan masyarakat"'. Sedangkan landasan filosofis mengacu pada semangat cita hukum yang diharapkan dari adanya suatu pengaturan.

\section{a. Makna "Delegated Legislation"}

Untuk dapat dilaksanakan di tataran yang lebih teknis, Undang-undang masih perlu dijabarkan lebih rinci. Melalui penjabaran ini kemudian dikenal konsep "Delegated Legislation". Terdapat beberapa referens yang dapat dirujuk untuk mendefinisikan istilah ini.

"Delegated Legislation is a term which covers the vast amount of legislation made by government agencies and the Governor-General under authority of Acts of Parliaments, which delegate this power to agencies. This type of legislation is also known as Subordinate Legislation or, since 2005, Legislative Instruments. Within the broad area of Delegated Legislation the following more specific terms are sometimes used:

- Regulation: the most common form of delegated legislation. Used for legislation of general application emanating from a

\footnotetext{
8 Yuliandri, Asas-asas Pembentukan Peraturan Perundang-undangan yang Baik: Gagasan pembentukan Undang-undang berkelanjutan, Jakarta, PT. Raja Grafindo Persada, 2009, hal. 134

${ }^{9}$ Ibid, hal 135
} 
government department. Published in the Statutory Rules series until 2004 and in the Select Legislative Instrument series from 2005

- Rule:

- Ordinance:

- By-law: ${ }^{10}$

Sebagaimana dikutip dari ... "Delegated legislation means permitting bodies beneath parliament to pass their own legislation. The three main forms of delegated legislation are statutory instruments, by-laws and orders in Council". ${ }^{11}$ Dari dua definisi ini dapat disimpulkan, bahwa produk legislasi atau undang-undang tentu saja dibuat oleh lembaga legislative, namun di luar itu juga diakui adanya aturan hukum yang dibuat selain oleh lembaga legislasi. Aturan hukum yang dibuat oleh selain lembaga legislasi ini juga diakui keberadaannya sebagai bagian dari produk perundang-undangan. Dasar dibentuknya aturan selain oleh lembaga legislasi ini berasal dari peraturan yang dibuat oleh badan legislasi itu sendiri. Siapakah badan selain badan legislasi yang dapat membuat produk perundang-undangan itu? Ialah badan eksekutif yang dengan kekuasaan pemerintahannya kemudian menjadi badan paling legitimate untuk mendapat pendelegasian pembentukan peraturan. Peraturan yang dibuat itu tidak lain dan tidak bukan ditujukan untuk kepentingan menerjemahkan lebih rinci produk legislasi agar dapat diimplementasikan dalam kehidupan bernegara.

Kata 'legislation' berasal dari dua kata bahasa latin, yaitu 'legis' yang berarti hukum dan 'latum' yang berarti membuat. Hal ini sesuai dengan pernyataan V.D. Mahajan sebagai berikut: "The term 'legislation' is derived from two Latin word, legis meaning law and latum meaning to make, put or set. Etymologically, legislation means the making or the setting of law". ${ }^{12}$

Mengutip pendapat Salmon dan Grey, V.D. Mahajan menyatakan "Menurut Salmond, legislasi adalah sumber hukum, berwujud aturan hukum yang dikeluarkan oleh lembaga yang berwenang. Menurut Gray, legislasi berarti "pernyataan formal dari badan legislative" (According to Salmond: "Legislation is that source of law which consists in the declaration of legal rules by a competent authority." According to Gray, legislation means "the formal utterances of the legislative organs of the society $\left.^{\prime \prime}\right) .{ }^{13}$

Menurut Salmond, terdapat dua jenis legislasi, yaitu legislasi utama (supreme legislation) dan legislasi delegasian (subordinate legislation). Legislasi utama ditetapkan oleh lembaga pemegang kedaulatan dalam negara. ${ }^{14}$ Legislasi utama ini tidak dapat dicabut, dihilangkan atau dikontrol oleh lembaga legislatif lain. Di lain pihak, legislasi delegasian merupakan produk dari lembaga lain di luar lembaga pemegang kedaulatan. Keberadaan dan keabsahan dari legislasi delegasian ini tergantung kepada lembaga yang mempunyai wewenang lebih tinggi. ${ }^{15}$

Pembentukan undang-undang (legislasi) di Indonesia dilaksanakan oleh Dewan Perwakilan Rakyat bersama-sama

\footnotetext{
${ }^{10}$ http://www.aph.gov.au/library/intguide/law/statutelaw.htm. Law Internet Resource, Parliamentary Library, Parliamentary of Australia

${ }^{11}$ Kierendeep Chahal, www.peterjepson.com/law.

12 V.D. Mahan, Op.Cit, h. 178.

${ }^{13}$ Ibid

14 Di Indonesia, menurut Pasal 1 ayat (2) UUDNRI Tahun 1945, kedaulatan di tangan rakyat dilaksanakan menurut Undang-Undang Dasar. Dengan demikian badan legislasi di Indonesia bukanlah pemegang kedaulatan utama. Demikian juga MPR bukanlah badan legislasi utama.

15 V.D. Mahayan, Op. Cit, h.179
} 
dengan Presiden. Hal ini sesuai dengan Ketentuan Pasal 20 UUDNRI TAHUN 1945 menyatakan:

(1) Dewan Perwakilan Rakyat mempunyai kekuasaan membentuk undang-undang.

(2) Setiap rancangan undang-undang dibahas oleh Dewan Perwakilan Rakyat dan Presiden untuk mendapat persetujuan bersama.

(3) Jika rancangan undang-undang itu tidak mendapatkan persetujuan bersama, rancangan undang-undang itu tidak boleh diajukan lagi dalam persidangan Dewan Perwakilan Rakyat masa itu.

(4) Presiden mengesahkan rancangan undang-undang yang telah disetujui bersama untuk menjadi undangundang.

(5) Dalam hal rancangan undang-undang yang telah disetujui bersama tersebut tidak disahkan oleh Presiden dalam waktu tiga puluh hari semenjak rancangan undang-undang tersebut disetujui, rancangan undang-undang tersebut sah menjadi undang-undang dan wajib diundangkan.

Konsep awal pembagian kekuasaan dimaksudkan bahwa lembaga legislatif adalah lembaga pembentuk undang-undang, lembaga eksekutif adalah lembaga pelaksana undang-undang, dan lembaga judisiil adalah lembaga yang menegakkan undang-undang terhadap pelanggar undang-undang. Dalam perjalanan waktu selanjutnya ternyata pembagian tersebut tidak dapat dilaksanakan secara tepat. Menurut Sir William Wade: ${ }^{16}$ "There is only a hazy borderline between legislation and administration, and the assumption that they are two fundamentally different form of power is misleading".
Lembaga legislatif, misalnya, tidak dapat memprediksikan secara tepat kebutuhan perundang-undangan masyarakat yang begitu cepat berubah. Kenyataan ini membawa akibat kepada banyaknya undangundang yang memberikan delegasi kepada pemerintah (executive) untuk menjabarkan lebih lanjut terhadap isi undang-undang yang tidak futuristik tersebut.

V.D. Mahayan yang menyatakan: ${ }^{17}$

Modern legislation is becoming highly technical and it is too much to expect that the ordinary members of Parliament will appreciate all the implications of modern legislation. Except a few experts in certain lines, the other members of Parliament are bound to bungle if they attempt to do the impossible. Under the circumstances, it is considered safe to approve of general principles of legislation and leave the details to the ministries concerned.

Senada dengan V.D. Dahajan, MP Jain menyatakan: ${ }^{18}$

The truth is that the legislature would be subjected to an impossible load of work if it were to endeavour to enact legislation by itself complete in all detail. It is therefore advisable to free the legislature from the task of enacting detail so that it may concentrate on the essential principles and policies underlying a bill. Also, if a law were to contain all the detail, it would become very prolix and cumbersome, and the common man might find it difficult to understand. Further, as most of the present day legislation pertains to socio-economic matters, the details inevitably tend to become technical and complex and only professional experts specialized in the subject-matter can work them out, rather than the legislators who are generalist and not specialist.

\footnotetext{
${ }^{16}$ Sir William Wade and Christopher Forsyth, Administrative Law, eighth edition, Oxford university Press, New York, 2000, h. 839

17 V.D. Dahajan, Op.Cit., h. 181-182

18 MP Jain, Administrative Law of Malaysia and Singapore, Third Edition, Malayan Law Journal, 1997, h. 42 .
} 
Menurut MP Jain, badan legislatif tidak mungkin melaksanakan pembentukan undang-undang secara komplit dan detail paling tidak dikarenakan tiga hal, yaitu: (i) lembaga legislatif pekerjaannya sudah terlalu banyak, (ii) undang-undang yang terlalu detail justru akan membingungkan rakyat pembacanya (penggunanya), dan (iii) pada saat ini di mana kemajuan di bidang sosial ekonomi begitu pesat, maka hanya mereka yang tergolong kelompok ekspert saja yang mampu memahami permasalahan secara detail.

Ketidakmungkinan lembaga legislatif dalam merumuskan undang-undang yang futuristic inilah yang menyebabkan adanya kecenderungan pendelegasian pengaturan lebih lanjut undang-undang (supreme legislation) ke dalam peraturan bawahan (subordinate legislation). Keadaan yang demikian kemudian telah memunculkan konsep 'delegated legislation'.

Dalam sejarah ketatanegaraan dunia, pendelegasian wewenang pengaturan undang-undang kepada peraturan yang lebih bawah ternyata tidak terjadi pada Abad 19 atau Abad 20-an, di mana kemajuan di bidang sosial-ekonomi maju begitu pesat. Abad 19 ini oleh A.V. Dicey disebut 'Periode kolektifisme' (The Period of Collectivism) yang dikatakan oleh Sir William Wade sebagai 'symptom of new era'. Pendelegasian kekuasaan pembentukan undang-undang kepada peraturan yang lebih bawah telah terjadi sejak abad 16, yaitu pada masa Pemerintahan Raja Inggris HenryVIII. ${ }^{19}$

Menurut M.P Jain, ${ }^{20}$ terminologi 'delegated legislation' adalah "used to denote: (1) the subsidiary legislation itself made by the administration in pursuance of the power delegated to it by the legislature, and (2) the exercise of the power by the agency.

Produk hukum dari badan legislatif adalah undang-undang (act of Parliament; Law), sedangkan produk hukum yang timbul dari 'delegated legislation' di tiaptiap negara berbeda, misalnya: 'regulation', 'rule', 'regulations', 'order', 'notification', dan 'bye-law'. Hal ini sesuai dengan pandangan Sir William Wade ${ }^{21}$ bahwa: "Parliament follows no particular policy in choosing the forms of delegated legislation; and there is a wide range of varieties and nomenclature. An Act may empower an authority to make regulation, rules or byelaws, to make order, or to give direction".

Pendelegasian wewenang legislasi ('delegated legislation') oleh badan legislatif melalui undang-undang di Indonesia juga tidak tertata dengan baik. Walaupun sejak Tahun 1966 telah diatur tentang Tata Urutas Peraturan Perundang-undangan, ternyata di dalam praktek hal tersebut tidak pernah dilaksanakan secara konsisten, misalnya tidak semua TAP MPR dijabarkan dengan undang-undang. Ketetapan MPR di bidang legislative dijabarkan ke dalam undangundang, sedangkan Ketetapan MPR di bidang eksekutif dijabarkan ke dalam Keputusan Presiden. Selain itu, Keppres tentang Repelita dilaksanakan dengan UU tiap-tiap tahun.

Menurut Ketetapan MPR No. III/ MPR/2000 Tata Urutan Peraturan Perundangundangan adalah sebagai berikut:

- UUDNRI TAHUN 1945

- TAP MPR

- UU

- Perpu

- PP

- Kepres

- Perda

\footnotetext{
${ }^{19}$ Lihat: Sir William Wade and Christopher Forsyd, Op. Cit., h. 840-841.

${ }^{20}$ MP Jain, Op. Cit, H. 41

${ }^{21}$ Sir William Wade and Christopher Forsyth, Op. Cit., h. 847.
} 
Dalam praktek ternyata urutan-ururan tersebut juga tidak dapat dijadikan pedoman. Sebagai contoh, apakah mungkin Presiden dalam setiap membentuk Kepres harus mendasarkan kepada PP?.

Dalam ketentuan Pasal 7 UU No.10 Tahun 2004 disebutkan sebagai berikut:

(1) Jenis dan hierarkhi Peraturan perundangundangan adalah sebagai berikut:
a. Undang-Undang Dasar Negara Republik Indonesia Tahun 1945;
b. Undang-Undang/Peraturan Pemerintah Pengganti Undang- undang;
c. Peraturan Pemerintah;
d. Peraturan Presiden;
e. Peraturan Daerah.

(2) Jenis Peraturan perundang-undangan selain sebagaimana dimaksud pada ayat (1), diakui keberadaannya dan mempunyai kekuatan hukum mengikat sepanjang diperintahkan oleh Peraturan Perundang-undangan yang lebih tinggi.

(3) Kekuatan hukum Peraturan Perundangundangan adalah sesuai dengan hierarkhi sebagaimana dimaksud pada ayat (1).

Penjelasan Pasal 7 ayat (4) UU No.10 Tahun 2004, menyatakan:

Jenis peraturan perundang-undangan selain
dalam ketentuan ini, antara lain peraturan yang
dikeluarkan oleh Majelis Permusyawaratan
Rakyat dan Dewan Perwakilan Rakyat, Dewan
Perwakilan Daerah, Mahkamah Agung,
Mahkamah Konstitusi, Badan Pemeriksa
Keuangan, Gubernur bank Indonesia, Menteri,
Kepala Bidang, Lembaga, atau Komisi yang
setingkat yang dibentuk oleh Undang-undang
atau pemerintah atas perintah undang-undang,
Dewan Perwakilan Rakyat Daerah Provinsi,
Gubernur, Dewan Perwakilan Rakyat Daerah
Kabupaten/Kota, Bupati/Walikota, Kepala
Desa atau yang setingkat.

Di dalam praktek penyelenggaraan negara di Indonesia, hierarki peraturan perundang-undangan sebagaimana diatur di dalam ketentuan Pasal 7 UU No.10 Tahun 2004 justru akan menyulitkan, oleh karenanya tidak akan dapat dilaksanakan secara konsisten. Sebagai contoh, untuk membentuk peraturan daerah dalam rangka pelaksanaan urusan wajib daerah tidak mungkin harus menunggu keluarnya Peraturan Presiden maupun Peraturan Pemerintah terlebih dahulu.

Di samping pembagian kekuasaan, konstitusi secara umum juga mengatur tentang hubungan antar kekuasaan. Terkait dengan tulisan ini, UUDNRI Tahun 1945 mengatur mekanisme hubungan Mahkamah Agung dengan Pemerintah. Pasal 24A ayat (1) UUDNRI Tahun 1945 menyatakan bahwa Mahkamah Agung berwenang menguji peraturan perundang-undangan di bawah undang-undang terhadap undangundang. Di dalam ketentuan Pasal 31 ayat (2) Undang-undang Nomor 14 Tahun 1985 menyatakan bahwa Mahkamah Agung menyatakan tidak sah peraturan perundangundangan di bawah undang-undang atas alasan bertentangan dengan peraturan yang lebih tinggi atau pembentukannya tidak memenuhi ketentuan yang berlaku.

Alasan adanya delegated legislation ini memang dibutuhkan sebagai peraturan pelaksana dari suatu undang-undang. Namun dasarnya tidak hanya sampai disitu, dalam tulisan Prof. Hermann Punder bahkan dibahas cukup komprehensif mengenai Democratic Legitimation Of Delegated Legislation. Dalam tulisan ini beliau membandingkan delegated legislation di 3 negara yakni, Amerika, Inggris dan Jerman. Delegated legislation adalah hal yang juga demokratis dan mutlak adanya mengingat pemerintah yang berkuasa juga merupakan pilihan rakyat yang dilaksanakan melalui pemilu. Dengan demikian legitimasi yang diberikan kepada pemerintah sebenarnya telah cukup kuat sebagai dasar bagi pemerintah untuk membuat aturan pelaksana di mana itu semua ditujukan untuk mengatur masyarakat.

Dalam konteks hukum Indonesia, 
produk legislasinya adalah undang-undang yang dibuat oleh DPR bersama dengan Presiden. Kemudian sebagai delegated legislation adalah peraturan di bawah undang-undang, di mana diatur dalam konstitusi Indonesia UUD NRI 1945 pasal 5 ayat (2), "Presiden menetapkan peraturan pemerintah untuk menjalankan undangundang sebagaimana mestinya". Kemudian dengan dasar hubungan antara pemerintah pusat dengan pemerintah daerah, pemerintah daerah dalam rangka mewujudkan otonomi dalam kerangka NKRI juga diberikan delegasi untuk membuat peraturan. "Pemerintah Daerah berhak menetapkan peraturan daerah dan peraturan-peraturan lain untuk melaksanakan otonomi dan tugas pembantuan"22.

Selanjutnya Prof. Maria Farida dalam bukunya membahas delegated legislation dengan istilah peraturan pelaksana (verordnung) yang disejajarkan juga dengan aturan otonom (autonome satzung). Peraturan pelaksana dan peraturan otonom ini merupakan peraturan-peraturan yang terletak di bawah undang-undang yang berfungsi menyelenggarakan ketentuanketentuan dalam undang-undang ${ }^{23}$. Pembeda dari peraturan pelaksana (verordnung) dan (autonome satzung) terletak pada sumber wewenangnya. Peraturan pelaksana bersumber dari kewenangan delegasi sedangkan peraturan otonom bersumber dari kewenangan atribusi ${ }^{24}$. Contoh dari atribusi kewenangan dalam pembentukan peraturan perundang-undangan diantaranya adalah sebagaimana diatur dalam pasal 22 ayat (1) mengenai kewenangan membentuk Perpu yang diberikan kepada Presiden jika terjadi ihwal kegentingan yang memaksa. Contoh lainnya adalah pasal 136 Undang-undang nomor 32 tahun 2004 tentang Pemerintahan Daerah yang memberikan kewenangan kepada Pemerintah Daerah untuk membentuk Perda yang dalam memberikan sanksi dibatasi dengan maksimal 6 bulan pidana kurungan dan maksimal denda Rp. 50.000.000,-. Sedangkan delegasi kewenangan diartikan sebagai pelimpahan kewenangan membentuk peraturan perundang-undangan yang dilakukan oleh peraturan yang lebih tinggi kepada peraturan yang lebih rendah baik dinyatakan dengan tegas maupun tindakan ${ }^{25}$. Contohnya sebagaimana yang diatur dalam pasal 15 ayat (3) Undang-undang nomor 2 tahun 2002 tentang Kepolisian Negara Republik Indonesia, "Tata cara pelaksanaan ketentuan sebagaimana dimaksud dalam ayat (2) huruf a dan d diatur lebih lanjut dengan Peraturan Pemerintah."

Sumber wewenang dalam pembentukan peraturan perundang-undangan ini menjadi penting jika dikaitkan dengan pasal 7 ayat (1) jis pasal 7 ayat (4), pasal 1 angka 2 Undang-undang nomor 10 tahun 2004. Pada pasal 1 angka 2, yang disebut sebagai peraturan perundang-undangan adalah peraturan tertulis yang dibuat oleh pejabat yang berwenang dan mengikat secara umum. Kemudian di pasal 7 ayat (1) yang menyebutkan jenis dan hierarkhi peraturan perundang-undangan dikatakan,

"Jenis dan hierarkhi peraturan perundangundangan adalah sebagai berikut:
a. UUD NRI 1945.
b. Undang-undang/Perpu
c. Peraturan Pemerintah
d. Peraturan Presiden
e. Peraturan Daerah

Selanjutnya, di pasal 7 ayat (4) disebutkan bahwa peraturan perundang-

\footnotetext{
22 Pasal 18 ayat (6), UUD NRI 1945

${ }^{23}$ Indrati, Maria Farida, Ilmu Perundang-undangan, Yogyakarta, Kanisius: 2007, hal. 55

${ }^{24}$ Ibid

${ }^{25}$ Ibid, hal 56
} 
undangan selain sebagaimana disebutkan dalam pasal 7 ayat (1) tetap diakui keberadaannya mempunyai kekuatan hukum mengikat sepanjang diperintahkan oleh peraturan perundang-undangan yang lebih tinggi. Frasa "sepanjang diperintahkan oleh peraturan yang lebih tinggi" mengandung arti bahwa yang dikatakan sebagai peraturan perundang-undangan bukan saja sebagaimana yang disebutkan di atas, namun termasuk juga Peraturan yang dikeluarkan oleh MPR dan DPR, DPD, MK, MA, BPK, Gubernur BI, Menteri, Kepala Bidang dst. yang dibentuk oleh Undang-undang atau Pemerintah atas perintah Undang-undang.

Hierarkhi didasarkan pada asas bahwa peraturan perundang-undangan yang lebih rendah tidak boleh bertentangan dengan peraturan yang lebih tinggi. Asas ini sebenarnya juga bermakna untuk menjaga konsistensi substansi suatu aturan hukum sehingga mampu menjamin adanya satu lajur kepastian hukum yang menghindari tumpang tindih aturan.

\section{b. Model-model Pendelegasian}

Pada teorinya setidaknya ada beberapa sumber wewenang yang menjadi dasar pembentukan peraturan perundangundangan. Sumber wewenang tersebut adalah Atribusi, Delegasi dan Mandat. Sumber wewenang yang ketiga yakni mandat, lebih sering digunakan dalam konteks perbuatan hukum pemerintah dalam kaitannya dengan hukum administrasi. Karena makna mandat adalah pelimpahan wewenang dari atasan kepada bawahan untuk melaksanakan tugas, sedangkan tanggumg jawab tetap dipegang pemberi mandat (atasan) ${ }^{26}$.

Pada subbab mengenai model-model pendelegasian pengaturan oleh Undangundang kepada pengaturan di bawahnya ini, pembahasan ditujukan pada penelusuran terhadap perundang-undangan sehingga nampak model dan macam pendelegasian yang ada. Undang-undang yang diambil sebagai case study dari tulisan ini adalah Undang-Undang Nomor 28 Tahun 2009 tentang Pajak Daerah dan Retribusi Daerah, disebutkan di pasal 155.

(1) Tarif Retribusi ditinjau kembali paling lama 3 (tiga) tahun sekali.

(2) Peninjauan tarif Retribusi sebagaimana dimaksud pada ayat (1) dilakukan dengan memperhatikan indeks harga dan perkembangan perekonomian.

(3) Penetapan tarif Retribusi sebagaimana dimaksud pada ayat (2) ditetapkan dengan Peraturan Kepala Daerah.

Kemudian di pasal berikutnya disebutkan Pasal 156

(1) Retribusi ditetapkan dengan Peraturan Daerah.

(2) Peraturan Daerah tentang Retribusi tidak dapat berlaku surut.

(3) Peraturan Daerah tentang Retribusi paling sedikit mengatur ketentuan mengenai:

a. nama, objek, dan Subjek Retribusi;

b. golongan retribusi

c. cara mengukur tingkat penggunaan jasa yang bersangkutan;

d. prinsip yang dianut dalam penetapan struktur dan besarnya tarif Retribusi;

e. struktur dan besarnya tarif Retribusi;

f. wilayah pemungutan;

g. penentuan pembayaran, tempat pembayaran, angsuran, dan penundaan pembayaran;

h. sanksi administratif;

i. penagihan;

j. penghapusan piutang Retribusi yang kedaluwarsa; dan

k. tanggal mulai berlakunya. 
Menurut pasal di atas bahwa Retribusi Daerah diatur dalam Peraturan Daerah, namun penetapan tarif yang diamanatkan oleh undang-undang harus dilakukan peninjauan paling lama 3 tahun sekali justru ditetapkan dengan Peraturan Kepala Daerah. Disini tidak terjadi kesederajatan produk hukum. Jika pada awalnya tarif retribusi ditetapkan melalui mekanisme perancangan Peraturan Daerah yang dibuat oleh Kepala Daerah bersama dengan DPRD yang notabene adalah perwakilan rakyat, mengapa kemudian peninjauannya diserahkan kepada Kepala Daerah secara sendirian? Di lain pihak, bukankah evaluasi Perda yang mengatur tentang Pajak harus melalui Gubernur jika itu perda Kabupaten/ Kota atau Mendagri jika perda Provinsi?

Model Pendelegasian yang lain adalah dari Undang-undang kepada Peraturan DPRD seperti tercantum dalam Pasal 389 dan 390 ayat (5) Undang-undang No. 27 Tahun 2009 tentang MPR, DPR, DPD dan DPRD.

\section{Pasal 389}

Ketentuan lebih lanjut mengenai tata cara pengajuan penggantian antarwaktu, verifikasi terhadap persyaratan calon pengganti antarwaktu, dan peresmian calon pengganti antarwaktu anggota DPRD kabupaten/kota diatur dengan peraturan pemerintah.

Pasal 390

(1) Anggota DPRD kabupaten/kota diberhentikan sementara karena:

a. menjadi terdakwa dalam perkara tindak pidana umum yang diancam dengan pidana penjara 5 (lima) tahun atau lebih; atau

b. menjadi terdakwa dalam perkara tindak pidana khusus.

(2) Ketentuan lebih lanjut mengenai tata cara pemberhentian sementara diatur dengan peraturan DPRD kabupaten/kota tentang tata tertib.
Adanya pasal ini menimbulkan beberapa kejanggalan bahwa untuk satu hal yang semestinya berada dalam satu rangkaian, mulai penggantian antarwaktu, pemberhentian sementara dan pemberhentian, mengapa delegasi produk hukumnya ke dua produk hukum yang berbeda? Lalu apakah kemudian sebagai produk hukum yang ada di bawah PP, perumusan peraturan DPRD tentang Tatib harus menunggu PP?

Berikutnya yang diangkat pada tulisan ini adalah Pasal 66 Undang-undang Nomor 43 Tahun 2009 mengenai arsip statis.

(1) Untuk kepentingan tulisan dan pengembangan ilmu pengetahuan, kepentingan penyelidikan dan penyidikan, arsip sebagaimana dimaksud pada ayat (1) dapat diakses dengan kewenangan kepala lembaga kearsipan yang ketentuannya diatur dengan peraturan kepala ANRI.

Sedangkan dalam pasal 67 Ketentuan lebih lanjut mengenai akuisisi, pengolahan, preservasi, dan akses arsip statis sebagaimana dimaksud dalam Pasal 60 sampai dengan Pasal 66 diatur dengan peraturan pemerintah. Dalam 2 pasal ini akses terhadap arsip statis terkesan diatur oleh 2 peraturan sekaligus yakni PP dan Peraturan Kepala ANRI. Pengaturan seperti ini tentu tumpang tindih.

\section{c. Akibat hukum pendelegasian pengaturan oleh Undang-Undang kepada pengaturan yang lebih rendah}

Dibuatnya aturan hukum sesungguhnya ditujukan agar aturan itu dapat ditegakkan secara maksimal, jika aturan yang telah dibuat itu dapat ditegakkan secara maksimal maka diharapkan akan dapat menciptakan dua hal; keadilan dan kepastian hukum. Dalam rangka mencapai kedua maksud ini maka diciptakanlah ajaran-ajaran dan 
perangkat-perangkat yang dapat digunakan untuk merancang, menerapkan hingga menguji suatu aturan hukum. Satu aturan hukum yang dibuat, kendati ditujukan untuk menyelesaikan masalah, tentu tidak mungkin bisa menyentuh semua sisinya secara menyeluruh. Untuk itulah suatu aturan hukum perlu didetailkan dari aturan yang umum hingga aturan yang teknis. Disinilah dibuat jenis dan macam aturan hukum. Setiap aturan hukum dibuat berjenjang dan setiap jenjang memiliki materi muatannya masing-masing. Dengan adanya aturan yang jelas maka diharapkan dapat menutup arena pilihan yang mengakibatkan ketidakjelasan penerapan hukum.

Masalahnya yang kemudian akan timbul adalah ketika ada ketidakselarasan atau tumpang tindih pengaturan antara aturan hukum yang lebih rendah terhadap aturan hukum yang lebih tinggi ataupun sesame aturan hukum dalam satu level dikarenakan oleh pendelegasian yang tidak tepat dalam Undang-undang. Hal ini tentu daja dapat memicu permasalahan hukum ditambah lagi permasalahan pendelegasian yang mengakibatkan tumpang tindih aturan hukum ini tidak dapat dijadikan alasan untuk melakukan judicial review ${ }^{27}$.

\section{PENUTUP}

Dalam beberapa peraturan perundangundangan yang menjadi perhatian dalam tulisan ini ditemukan adanya model pendelegasian wewenang oleh Undangundang terhadap peraturan yang lebih rendah, dimana dalam pendelegasian itu ternyata terdapat norma yang tidak tepat. Seperti yang terjadi dalam Undang-undang Pajak Daerah dan Retribusi, disebutkan bahwa Retribusi diatur dalam Peraturan
Daerah, namun penetapan tarif yang diamanatkan oleh undang-undang harus dilakukan peninjauan paling lama 3 tahun sekali justru ditetapkan dengan Peraturan Kepala Daerah.

Manfaat dari konsistensi pendelegasian oleh Undang-undang terhadap peraturan di bawahnya sebenarnya adalah untuk menjamin adanya satu lajur kepastian hukum yang menghindari tumpang tindih aturan. Perlu dipertimbangkan bahwa aturan hukum yang lebih rendah tidak boleh bertentangan dengan aturan hukum yang lebih tinggi, sehingga seharusnya aturan hukum secara tertib dan bertahap didelegasikan ke peraturan yang setingkat di bawahnya, lalu setingkat lagi di bawahnya, agar setiap aturan hukum tidak mengatur melebihi yang didelegasikannya. Selain itu fungsi guideline dari aturan yang lebih tinggi adalah untuk menghasilkan aturan yang semakin ke bawah semakin detail, rigid, teknis dan prosedural sehingga tidak membuka arena pilihan yang dapat disalahgunakan dan aturan hukum yang sudah dibuat dapat ditegakkan secara maksimal.

Berdasarkan kesimpulan yang didapat, maka saran yang dapat dikemukakan melalui tulisan ini adalah Legal Reform Oriented, seyogyanya menjadi semangat para pengambil kebijakan dan perancang peraturan ketika merumuskan produk legislasi dan regulasi. Hal ini tidak lain dan tidak bukan adalah untuk memperbaiki perwajahan hukum itu sendiri. Sekali lagi peraturan-perundang-undangan merupakan "hukum" dan "tools" untuk meraih tujuan kehidupan bernegara yang lebih baik. Di samping itu, reformasi hukum dan penegakan praktek hukum tidak akan berubah tatkala

\footnotetext{
${ }^{27}$ Hoesein, Zainal Arifin, Judicial Review di Mahkamah Agung RI (tiga dekade pengujian peraturan perundangundangan), Jakarta:Rajawali Press, h. 197
} 
normatifnya tidak dibenahi dengan baik. Sampai dengan keberlakuannya, peraturan prundang-undangan telah melewati proses yang panjang, biaya yang besar, juga sumber daya yang tidak sedikit. Sesungguhnya ini merupakan suatu kerugian ketika produk hukum yang telah dihasilkan kemudian tidak bisa dilaksanakan dengan baik, tidak bias diimplementaiskan dengan baik, atau bahkan aturan yang dibuat untuk menyelesaikan masalah ini justru menimbulkan masalah baru. Kerugian ini semestinya dapat dihindari jika drafter memperhatikan guidline perancangan secara seksama. Menaati kaidah-kaidah naskah akademik serta kaidah-kaiadah penormaan, juga memperhatikan hierarkhi peraturan perundang-undangan. Dalam kajian ROCCIPI, Huruf R yang berarti analisa tentang "Rule" sangat penting dilakukan dengan teliti. Pisau analisis ini mengharuskan agar researcher mengumpulkan semua aturan-aturan hukum yang terkait dengan masalah yang hendak diangkat dalam peraturan perundangundangan dengan pertanyaan inti apakah sebelumnya ada peraturan yang mengatur, atau apakah pengaturan tentang masalah ini akan beririsan dengan aturan yang lain? Kajian mengenai Rule ini tidak saja terhadap aturan hukum yang lebih tinggi namun juga terhadap kemungkinan adanya peraturan yang lebih rendah. Sinkronisasi Peraturan Perundang-undangan. Pekerjaan ini agaknya patut menjadi tugas berat Kementrian Hukum dan HAM. Sinkronisasi ini penting dilakukan untuk menghindari inefisiensi peraturan perundang-undangan. Terlalu banyaknya aturan hukum yang saling tumpang tindih akan menyulitkan Law Impemeting Agencies dalam menegakkan aturan.

\section{DAFTAR PUSTAKA}

Asshiddiqie, Jimly, Perihal Undang-undang, Rajawali Pers, Jakarta, 2010.

Bahan Tayangan Materi Sosialisasi UUD NRI 1945, Sekretariat Jenderal MPR RI, Jakarta, 2009.

Hadjon, Philipus M., Tentang Wewenang, Fakultas Hukum UNAIR, Jurnal Ilmiah Yuridika, Surabaya, 1997.

Hoesein, Zainal Arifin, Judicial Review di Mahkamah Agung RI Tiga DekadePengujian Peraturan Perundang-undangan, Rajawali Pers, Jakarta 2009.

Indrati, Maria Farida, Ilmu Perundang-undangan 1, Kanisius, Yogyakarta, 2007.

Ikhtisar Putusan Mahkamah Konstitusi tahun 2003-2008, Sekretariat Mahkamah Konstitusi, Jakarta, 2008.

Kelsen, Hans, General Theory of Law and State, Russell \& Russell, New York, 1945.

Natabaya, A.S., "Menata Ulang Sistem Peraturan Perundang-undangan di Indonesia", Sekretariat Jenderal MK RI, Jakarta, 2008.

Marzuki, Peter Mahmud, Penelitian Hukum, Kencana, Jakarta, 2009.

Yuliandri, Asas-asas Pembentukan Peraturan Perundang-undangan yang Baik: Gagasan pembentukan Undang-undang berkelanjutan, PT. Raja Grafindo Persada, Jakarta, 2009.

Siti Sundari Rangkuti, Hukum Lingkungan dan Kebijaksanaan Lingkungan Nasional (edisi ketiga), Airlangga University Press, Surabaya, 2005.

Sir William Wade and Christopher Forsyth, Administrative Law, eighth edition, Oxford university Press, New York, 2000.

ELSAM (Lembaga Studi dan Advokasi Masyarakat), Position Paper Advokasi RUU KUHPSeri\#1 Asas Legalitas Dalam Rancangan KUHP, 2008. 
Peraturan Perundang-undangan:

UUD NRI 1945.

Undang-undang Nomor 10 Tahun 2004 tentang Pembentukan Peraturan PerundangUndangan.
Undang-undang Nomor 27 Tahun 2009 tentang MPR, DPR, DPD dan DPRD.

Undang-undang Nomor 43 Tahun 2009 tentang Kearsipan.

Undang-undang Nomor 28 Tahun 2009 tentang Pajak Daerah dan Retribusi Daerah. 